\title{
Irrigation, a Basic Technological Element, for Improving the Autumn Cabbage Yield in Crișurilor Plain, Western Romania
}

\author{
Cristian G. DOMUȚA ${ }^{1 *}$, Ana C. PEREȘ ${ }^{2}$, Radu P. BREJEA ${ }^{2}$, \\ Ioana M. BORZA ${ }^{1}$, Eugen $\mathrm{JUDE}^{2}$, Nandor KÖTELES ${ }^{2}$, \\ Nicolae CENUȘA ${ }^{2}$, Mariana F. BEI ${ }^{3}$ \\ ${ }^{1}$ University of Oradea, Faculty of Environmental Protection, Department of Agriculture and Horticulture, 26 Gen. Magheru St., 410048 \\ Oradea,Romania; cristian_domuta@yahoo.com ("correspondingauthor); borzaioanamaria@yahoo.com \\ ${ }^{2}$ University of Oradea, Faculty of Environmental Protection, Department of Environmental Engineering, 26 Gen. Magheru St., 410048 Oradea, \\ Romania;peresana35@yahoo.com; rbrejea@yahoo.com;jdeugen@yahoo.com; kotelesnandor@yahoo.com; cenusa.nicolae@yahoo.com; \\ ${ }^{3}$ University of Oradea, Faculty of Environmental Protection, Department of Food Science Engineering, 26 Gen. Magheru St., 410048 Oradea, \\ Romania;domocosmariana@yahoo.com
}

\begin{abstract}
The researches were carried out at the Agricultural Research and Development Station, Crișurilor Plain, Oradea, during 1990-2016. They have demonstrated that irrigation is needed every year due to the extension of the drought regions in Romania. Irrigation has become a basic element in the technology of the autumn cabbage crop due to the yearly pedological drought. For cabbage, the minimum watering depth is considered $0-50 \mathrm{~cm}$, while an irrigation average rate of $2,410 \mathrm{~m}^{3} / \mathrm{ha}$, with a variation range of $1,330-4,900 \mathrm{~m}^{3} / \mathrm{ha}$ had to be imposed in order to maintain the soil moisture content on the watering depth between the easily available water content and the field capacity. Irrigation improved the microclimate conditions and the ratio water/temperature + light (Domuța climate index) increased. Daily water consumption increased as well. As a result, total water consumption increased by $70 \%$, with a variation range of $19-872 \%$. Irrigation determined an yield gain of $153 \%$; water use efficiency $\left(\mathrm{kg} / \mathrm{m}^{3}\right)$ increased by $60.0 \%$; irrigation water use efficiency recorded an average value of $13.4 \mathrm{~kg}$ yield gain $/ \mathrm{m}^{3}$, with variation range $6.7 \mathrm{~kg}$ yield gain $/ \mathrm{m}^{3}-24.2 \mathrm{~kg}$ yield gain $/ \mathrm{m}^{3}$. The correlations quantified in the soil-water-plant system (number of days with pedological drought, yield, respectively yield gain; Domuța climate index-yield; water consumption-yield) support irrigation for the autumn cabbage crop from Crişurilor Plain.
\end{abstract}

Keywords: Domuța climate index, pedological drought, water consumption, water use efficiency, yield, yield gain

\section{Introduction}

A great number of vegetable species, varieties and forms are important elements for a wide range of food with valuable ingredients, significantly improving and enriching meal choices (Posta and Berar, 2007). Staggered production cycles and the constant need to supply markets with fresh vegetables have become crucial issues. Adding various vegetables to daily meals has to be possible all year round, not only during the top harvesting seasons. Besides supplying markets with fresh products, vegetables are also important as raw materials for the food industry (Laczi et al., 2014).
The origin of the cabbage is the basin of the Mediterranean Sea. It was harvested in Antiquity by Greeks, Romans and Chinese. Western and Eastern Europeans have been harvesting it on large scales since the $11^{\text {th }}-12^{\text {th }}$ centuries. Cabbage can be consumed in many forms (fresh, pickled, dried or frozen) thanks to its content in vitamins $\left(\mathrm{A}, \mathrm{B}_{1}, \mathrm{~B}_{2}, \mathrm{C}, \mathrm{PP}, \mathrm{K}\right)$ and mineral salts $(\mathrm{Ca}, \mathrm{Fe}, \mathrm{Cu}, \mathrm{P}, \mathrm{Zn}$, $\mathrm{Cl}, \mathrm{Na}$ ) (Csok et al., 2007; Stoleru and Imre, 2007).

Cabbage requires a high amount of water. Domuța (2008) highlighted the correlation between water requirements and production levels (Frantz et al., 1999; Apahidean et al., 2011). Compared to fruit trees, it was more difficult for leafy vegetables, including cabbage, to adapt to water deficit (Jones, 2004; Costa et al., 2007). Results of the influence of water deficit on cabbage yield presented several discrepancies due to differences in harvesting, climate, soil and irrigation method. 
Analysing the influence of fertilization by tank sprinkler and by drip irrigation on the white cabbage from sandy soils, Sturm et al. (2010) found out that the yield, the nitrogen uptake in the plant $(246 \mathrm{~kg} / \mathrm{ha})$ and the efficient use of fertilisers registered significantly increased values when tank sprinkler was used as compared to drip irrigation. However, drip irrigation, which covered $100 \%$ of the crop's water requirements, did not ensure the highest yield due to the sandy soil the experiment was conducted on.

Compared to furrow irrigation, drip irrigation is the most effective method to irrigate vegetable crops thanks to water savings and yield increases (Tiwari et al., 1998a,b; Xie et al., 1999; Tiwari et al., 2003).

A study conducted on the cabbage growth and yield concluded that a water deficit at 50\% ETc led to significant decreases of the yield, cabbage head size, fresh weight and relative water content as compared to a water deficit at $75 \%$ ETc (ETc - consumptive use of water, or evapotranspiration). Both cases indicated that the decrease of the marketable and total yield was influenced by the relative water content (Xu and Leskovar, 2014).

Analysing the effect of irrigation on the growth of white cabbage on a loamy sand soil near Dresden, Germany, Seidel et al. (2017) concluded that drought stress led to reduced yields, reduced plant height and diminished quality coefficients of the cabbage heads. Based on optimal ETc and soil water balance, early drought stress effects could be compensated by an appropriate water supply in later growing stages.
ETc is defined as the amount of water required by a crop for optimal growth. Eto was determined using measured climate data and the required $\mathrm{Kc}$ factors were provided by the FAO for a multitude of plants (Allen et al., 1998).

For all these, researches on the irrigation of the autumn cabbage crops from Crisurilor Plain, a geographic formation in North-Western Romania, were initiated by Domuta in 1990.

\section{Materials and Methods}

\section{Description of the study site}

Researches were carried out at the Agricultural Research and Development Station from Oradea during 1990-2016.

The preluvo-soil from research site was well structured, the aggregates representing $47.5 \%$. On the watering depth of the autumn cabbage crop, the soil had a wilting point of $9.7 \%\left(720 \mathrm{~m}^{3} / \mathrm{ha}\right)$ and the field capacity was $24 \%(1,787$ $\mathrm{m}^{3} / \mathrm{ha}$ ); the clay content determined the easily available water content at $2 / 3$ of the ratio field capacity, wilting point. Its value was of $19.2 \%\left(1,431 \mathrm{~m}^{3} / \mathrm{ha}\right)$ (Table 1$)$. Research soil presented a weak acid reaction on the entire studied depth, with values increasing from surface towards the depth (Samuel et al., 2011). The supply with humus was poor and also the supply with total nitrogen was poor ranging to average on the entire studied depth (Table 2).

The source for irrigation was a well that provided irrigation water with very good chemical properties $(\mathrm{CSR}=$ -187; SAR $=0.53$ in 2007-2009) (Table 3).

Table 1. Physical and hydro-physical properties of the preluvo-soil from research site, Oradea

\begin{tabular}{|c|c|c|c|c|c|c|c|c|c|c|c|}
\hline \multirow{2}{*}{$\begin{array}{l}\text { Depth } \\
-\mathrm{cm}-\end{array}$} & \multirow{2}{*}{$\begin{array}{c}\text { Total aggregates } \\
\%\end{array}$} & \multirow{2}{*}{$\begin{array}{c}\text { Clay } \\
0.002 \%\end{array}$} & \multirow{2}{*}{$\begin{array}{c}\mathrm{BD} \\
\mathrm{g} / \mathrm{cm}^{3}\end{array}$} & \multirow{2}{*}{$\begin{array}{c}\mathrm{K} \\
\mathrm{mm} / \mathrm{h}\end{array}$} & \multirow{2}{*}{$\begin{array}{l}\mathrm{TP} \\
\%\end{array}$} & \multicolumn{2}{|c|}{$\mathrm{FC}$} & \multicolumn{2}{|c|}{ WP } & \multicolumn{2}{|c|}{ Wea } \\
\hline & & & & & & $\%$ & $\mathrm{~m}^{3} / \mathrm{ha}$ & $\%$ & $\mathrm{~m}^{3} / \mathrm{ha}$ & $\%$ & $\mathrm{~m}^{3} / \mathrm{ha}$ \\
\hline $0-20$ & 47.5 & 31.5 & 1.41 & 21.0 & 21 & 24.2 & 682 & 9.2 & 259 & 19.2 & 542 \\
\hline $20-40$ & - & 34.1 & 1.52 & 10.5 & 49 & 23.6 & 717 & 9.4 & 286 & 18.9 & 575 \\
\hline $40-60$ & - & 39.8 & 1.58 & 4.4 & 48 & 25.1 & 768 & 11.1 & 351 & 19.9 & 630 \\
\hline $60-80$ & - & 39.3 & 1.65 & 1.0 & 43 & 24.4 & 828 & 10.8 & 356 & 20.4 & 672 \\
\hline $80-100$ & - & 38.8 & 1.57 & 0.5 & 40 & 23.8 & 766 & 12.2 & 383 & 20.4 & 640 \\
\hline $100-150$ & - & 37.6 & 1.54 & 0.1 & 39 & 24.0 & 1,833 & 14.2 & 1093 & 20.6 & 1,586 \\
\hline $0-50$ & - & - & 1.49 & - & - & 24.0 & 1,787 & 9.7 & 720 & 19.2 & 1,431 \\
\hline $0-150$ & - & - & 1.55 & - & - & 24.1 &, 5611 & 11.7 & 2,720 & 20.0 & 4,646 \\
\hline
\end{tabular}

Table 2. The chemical properties of the preluvo-soil from research site, Oradea

\begin{tabular}{|c|c|c|c|c|c|c|c|c|}
\hline Depth & $\mathrm{pH}$ & $\mathrm{V}$ & Humus & $\mathrm{N}_{\text {total }}$ & $\mathrm{P}_{\mathrm{AL}}$ & $\mathrm{K}_{\mathrm{AL}}$ & $\mathrm{Mg}^{2+}$ & $\mathrm{Mn}^{2+}$ \\
\hline$-\mathrm{cm}-$ & $\left(\mathrm{H}_{2} \mathrm{O}\right)$ & $\%$ & $\%$ & $\%$ & \multicolumn{4}{|c|}{ Ppm } \\
\hline $0-20$ & 6.9 & 79.9 & 1.8 & 0.128 & 149.9 & 120.6 & 256 & 32 \\
\hline $20-40$ & 6.12 & 71.1 & 1.74 & 0.160 & 125.0 & 121.0 & 301 & 28 \\
\hline $40-60$ & 6.37 & 86.0 & 1.47 & 0.157 & 39.3 & 127.4 & 396 & 21 \\
\hline $60-80$ & 6.41 & 86.2 & - & - & 26.0 & 129.6 & 420 & 21 \\
\hline $80-100$ & 6.63 & 86.3 & - & - & 24.0 & 130.2 & 490 & 20 \\
\hline
\end{tabular}

Table 3. The average values of the chemical indexes of the irrigation water used in research site

\begin{tabular}{|c|c|c|c|c|c|c|c|c|c|}
\hline $\mathrm{Ca}^{2+}$ & $\mathrm{Mg}^{2+}$ & $\mathrm{Na}^{+}$ & $\mathrm{K}^{-}$ & $\mathrm{CO}_{3}^{2-}$ & $\mathrm{HCO}_{3}$ & $\mathrm{CL}^{-}$ & & $\mathrm{SO}_{4}^{2-}$ & \\
\hline \multicolumn{10}{|c|}{$\mathrm{mg} /$ litre } \\
\hline 49.1 & 44.0 & 20.8 & 2.7 & - & 266.8 & 35.4 & & 80.3 & \\
\hline \multicolumn{2}{|c|}{$\mathrm{pH}$} & $\mathrm{Na} \%$ & & Fixed miner & lue $\mathrm{g} / \mathrm{l}$ & SAR & CSR & & N.Florea class \\
\hline \multicolumn{10}{|c|}{$\mathrm{mg} /$ litre } \\
\hline \multicolumn{2}{|c|}{7.3} & 12.9 & \multicolumn{3}{|c|}{0.5} & 0.53 & -1.8 & & II \\
\hline
\end{tabular}


584

The irrigation installation from the research site allowed a precise measurement and an even distribution of the irrigation water.

\section{Experimental procedure}

The soil moisture was determined every 10 days, using the gravimetric method on $0-50 \mathrm{~cm}$ depth and the neutron method on 50-150 cm depth. By means of irrigation, the soil water reserve was maintained at a depth of $0-50 \mathrm{~cm}$ above the easily available water content. The following formula was used to determine the water reserve:

$\mathrm{Wr}=\mathrm{U} \times \mathrm{BD} \times \mathrm{H}$

where: $\mathrm{Wr}=$ water reserve, $\mathrm{m}^{3} / \mathrm{ha} ; \mathrm{BD}=$ bulk density, $\mathrm{g} / \mathrm{cm}^{3} ; \mathrm{H}=$ depth, $\mathrm{cm}$.

Domuța (1995) described the pedological drought using two indexes: pedological drought the period with soil water reserve on watering depth below the easily available water content) and strong pedological drought (the period with soil water reserve on watering depth below the wilting point). In order to count the days with pedological drought below the easily available water content and below the wilting point, several graphs of the dynamics of the soil water reserve were set up based on gravimetric determinations of the soil moisture.

Water consumption was determined by the soil water balance equation; 0-150 cm depth was used for balance. The following formula was used:

$\mathrm{Ri}+\mathrm{Pv}=\mathrm{Rf}+\Sigma(\mathrm{e}+\mathrm{t})$

where: $\mathrm{Ri}=$ initial water reserve (at the planting), $\mathrm{m}^{3} / \mathrm{ha} ; \mathrm{Pv}=$ rainfall registered during cabbage planting and harvesting, $\mathrm{m}^{3} / \mathrm{ha}$; $\mathrm{Rf}=$ final reserve (at harvesting), $\mathrm{m}^{3} / \mathrm{ha}$; $\Sigma(\mathrm{e}+\mathrm{t})=$ total water consumption, $\mathrm{m}^{3} / \mathrm{ha}$.

The "Domuta climate index" (ICD) (Domuța, 1995) was used to characterize the microclimate, with the following formula:

$$
\mathrm{ICD}=\frac{100 W+12,9 A}{\sum t+S b}
$$

where: $\mathrm{W}=$ water (rainfall, irrigation, groundwater), $\mathrm{mm} ; \mathrm{A}=$ air humidity $(\%) ; \mathrm{t}=$ temperature $\left({ }^{\circ} \mathrm{C}\right) ; \mathrm{Sb}=$ sun brilliance (hour).

According to ICD values, there are several types of conditions: excessively drought $(<3)$; very drought (3.15.0); drought (5.1-7.0); average drought (7.1-9.0); average wet (9.1-12.0); wet I (12.1-15.0); wet II (15.1-18.0); wet III (18.1-25.0); excessively wet $(>25)$.

To calculate the water use efficiency (WUE) the following formula was used:

$$
\mathrm{WUE}=\frac{\mathrm{Y}}{\sum(\mathrm{e}+\mathrm{t})} \quad\left[\mathrm{kg} / \mathrm{m}^{3}\right]
$$

where: $\mathrm{Y}=$ yield $(\mathrm{kg} / \mathrm{ha}) ; \sum(\mathrm{e}+\mathrm{t})=$ water consumption $\left(\mathrm{m}^{3} / \mathrm{ha}\right)$.
Irrigation water use efficiency (IWUE) was calculated according to the following formula:

$$
\text { IWUE }=\frac{Y_{i}-Y_{n}}{\sum m} \quad\left[\mathrm{~kg} \text { gain } / \mathrm{m}^{3}\right]
$$

where: $Y_{\mathrm{i}}=$ irrigated yield $(\mathrm{kg} / \mathrm{ha}) ; \mathrm{Y}_{\mathrm{n}}=$ non-irrigated yield $(\mathrm{kg} / \mathrm{ha}) ; \sum \mathrm{m}=$ irrigation water amount $\left(\mathrm{m}^{3} / \mathrm{ha}\right)$.

Harvesting and calculation of results were performed observing the instructions provided for such experiments in specialised literature. Variance analysis was used in order to interpret the results.

\section{Results}

On average, throughout the entire studied period, the main climate elements show a draughtier situation than the multiannual average: the annual average air temperature increased to $11.1^{\circ} \mathrm{C}$ vs. $10.2^{\circ} \mathrm{C}$; air humidity decreased to $75 \%$ vs. $78 \%$, sunshine increased to $2,159.5$ vs. $2,097.1$ hours, while annual rainfall was very close to the multiannual average of $622.7 \mathrm{~mm}$ vs. $613.7 \mathrm{~mm}$.

\section{Pedological drought in non-irrigated autumn cabbage crops \\ Pedological drought is defined as the total number of} days with soil water reserve below the easily available water content on watering depth $(0-50 \mathrm{~cm})$. The analysis of the annual graphs of soil water reserve showed the presence of the pedological drought every year under study (1990-2016) in August (27 days) and September (23 days). In July, the frequency of the phenomenon was of $82 \%$ (21 days) and in June of $50 \%$ ( 8 days). The total number of days with pedological drought had an average value of 80 days, with a variation range of 8-112 days (Table 4).

A reverse correlation was quantified during the interval 2012-2016 between the number of days with pedological drought and water consumption $\left(\mathrm{y}=0.204 \mathrm{x}^{2}-21.75 \mathrm{x}+\right.$ 787.32; $\left.\mathrm{R}^{2}=0.9403\right)$ and between this drought indicator and the yields $\left(\mathrm{y}=16.193 \mathrm{Ln}(\mathrm{x})+1.9937 ; \mathrm{R}^{2}=0.8674\right)$ (Fig. 1 a,b).

There was a direct connection, very significant statistically speaking, between the number of days with pedological drought and the yield gain determined by irrigation $\left(\mathrm{y}=-0.0113 \mathrm{x} 2+1.4351 \mathrm{x}-5.1845 ; \mathrm{R}^{2}=0.962\right)$ (Fig. 1c).

\section{Optimal irrigation regime}

In order to maintain the soil water reserve between the easily available water content and field capacity, an irrigation rate of $2,410 \mathrm{~m}^{3} / \mathrm{ha}$, with a variation range between $1,330-$ $4,900 \mathrm{~m}^{3} /$ ha was used for the entire study period (1990 -

\begin{tabular}{|c|c|c|c|c|c|}
\hline \multirow{2}{*}{ Specifications } & \multicolumn{4}{|c|}{ Month } & \multirow{2}{*}{ Total } \\
\hline & June & July & August & September & \\
\hline Minimum value & 0 & 0 & 3 & 5 & 8 \\
\hline Maximum & 20 & 31 & 31 & 30 & 112 \\
\hline Average & 8 & 21 & 27 & 23 & 80 \\
\hline Frequency of the pedological drought & 50 & 82 & 100 & 100 & 100 \\
\hline
\end{tabular}
2016) (Table 5).

Table 4. Analysis of the pedological drought (days) in non-irrigated cabbage crop 

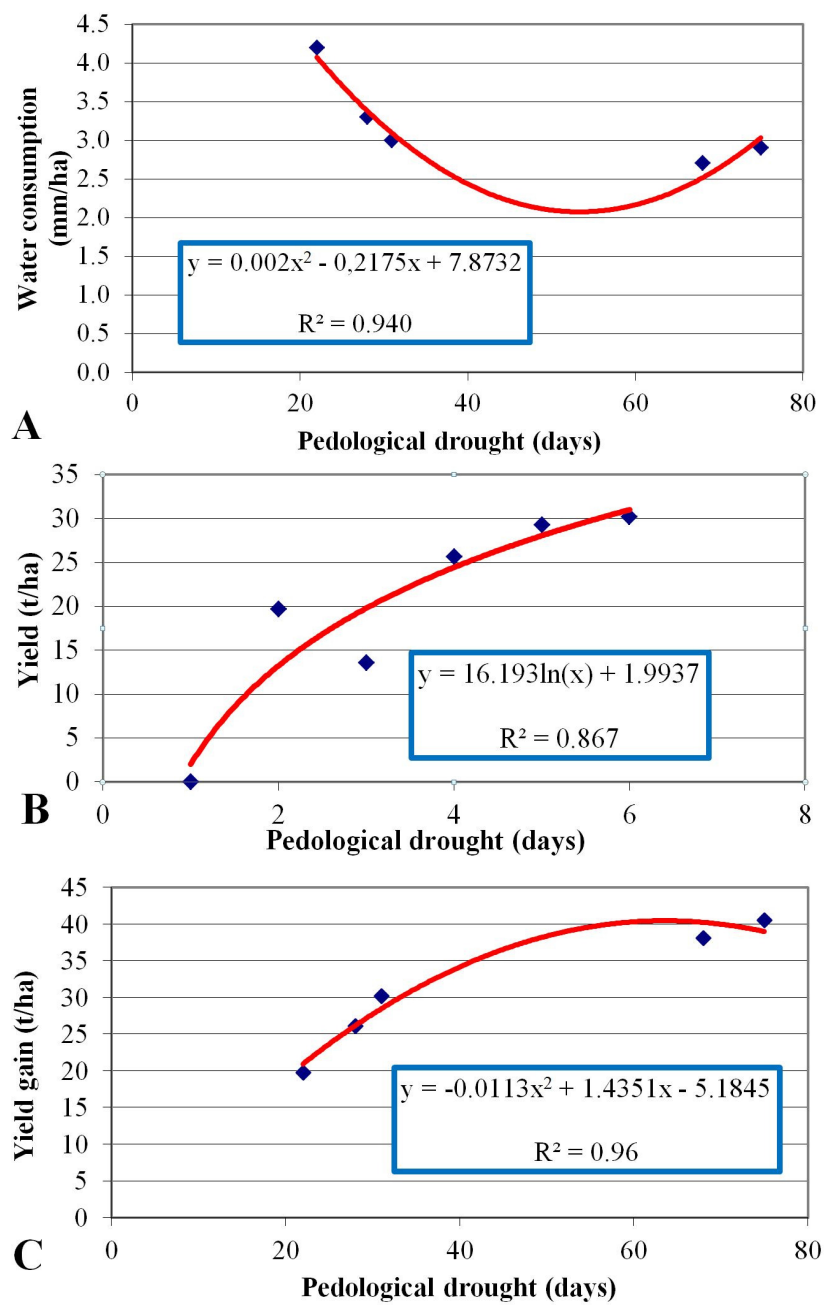

Fig. 1. Correlation of the pedological indexes in autumn cabbage crop

The average monthly irrigation rate was of $1,114 \mathrm{~m}^{3} / \mathrm{ha}$ (variation range $500-2,100 \mathrm{~m}^{3} / \mathrm{ha}$ ) in August, of $714 \mathrm{~m}^{3} / \mathrm{ha}$ $\left(0-1,560 \mathrm{~m}^{3} / \mathrm{ha}\right)$ in July, of $312 \mathrm{~m}^{3} / \mathrm{ha}\left(0-880 \mathrm{~m}^{3} / \mathrm{ha}\right)$ in June and of $270 \mathrm{~m}^{3} / \mathrm{ha}\left(0-1,100 \mathrm{~m}^{3} / \mathrm{ha}\right)$ in September, with considerable variability among months.

The influence of irrigation on the microclimate of the autumn cabbage

The use of the irrigation led to important microclimate changes affecting the crop.
One approach of characterizing microclimate is based on the use of climate indicators. Climate indicators may use one element of the climate, like temperature (the Thornthwaite index) or rainfall (the Topor index), two elements of the climate, like temperature and rainfall (the Martonne aridity index), the Seleaninov index, the Teaci index etc.). On average, during the entire period studied, the microclimate the interval between June and September was characterized as "average wet" (ICD $=9.8)$ for the nonirrigated crop compared to "wet" for the irrigated one (ICD $=16.5$ ). On average, a difference of $68 \%$, with a variation range between 12-359, was recorded in August. The highest difference recorded was also in August (161\%, variation range 10-1,666). In July, the difference was of $79 \%$, variation range 9-270. In June, the difference was of $40 \%$, variation range 0-373 and in September, the difference was of 34\%, variation range 0-359 (Table 6).

The direct relationships between the Domuța climate index and the water consumption index $\left(y=27.017 \mathrm{x}^{1.0925}\right.$; $\mathrm{R}^{2}=0.9636$ ) and those between the Domuța climate index and the yield $\left(\mathrm{y}=0.9586 \mathrm{x}^{1.3916} ; \mathrm{R}^{2}=0.8102\right)$ were quantified for the interval 2006-2016 (Fig. 2 a,b).

\section{The influence of irrigation on water consumption}

Throughout the growing season, daily water consumption increased for the irrigated autumn crop compared to the non-irrigated one (Fig. 3). The highest difference $\left(29 \mathrm{~m}^{3} / \mathrm{ha}\right)$ was recorded in August. At the same time, irrigation resulted in a statistically better regression function when compared to the non-irrigated variant: $y=-$ $0.0123 x^{2}+1.44 x+17.375 ; R^{2}=0.9273$ vs. $y=-0.0043 x^{2}+$ $0.4307 x+21.835 ; R^{2}=0.7941$

Consequently, the total water consumption for the irrigated autumn cabbage increased by $70 \%$ for the whole time interval under study $\left(5,180 \mathrm{~m}^{3} / \mathrm{ha}\right.$ vs. $\left.3,045 \mathrm{~m}^{3} / \mathrm{ha}\right)$. The variation range of the total water consumption was between $1,073-4,421 \mathrm{~m}^{3} /$ ha for the non-irrigated autumn cabbage and of 4,375- $6,200 \mathrm{~m}^{3} / \mathrm{ha}$ for the irrigated autumn cabbage (Table 7).

Irrigation represented the main source in supplying the total water consumption for the irrigated autumn cabbage (47\%). The amount of rainfall recorded from plantation to harvesting represented $46 \%$. The water used from soil water reserve represented $7 \%$. The amount of water used from the soil reserve was of $656 \mathrm{~m}^{3} / \mathrm{ha}$ for the non-irrigated variant and of $380 \mathrm{~m}^{3} /$ ha for the irrigated one (Fig. 4).

Table 5. The irrigation regime $\left(\mathrm{m}^{3} / \mathrm{ha}\right)$ used to maintain the soil water reserve between the easily available water contend and field capacity in autumn cabbage crop

\begin{tabular}{cccccc}
\hline \multirow{2}{*}{ Specifications } & \multicolumn{3}{c}{ Month } & \multicolumn{2}{c}{ July-September } \\
\cline { 2 - 5 } & June & July & August & September & 1,330 \\
Minimum value & 0 & 0 & 500 & 0 & 4,900 \\
Maximum value & 880 & 1,560 & 2,330 & 1,010 & 2,410 \\
Average & 312 & 714 & 1,114 & 270 & \\
\hline
\end{tabular}

Table 6. The influence of irrigation on the microclimate (Domuța climate index, ICD) of the autumn cabbage crop

\begin{tabular}{|c|c|c|c|c|c|c|c|c|c|c|}
\hline \multirow{3}{*}{ Variant } & \multicolumn{10}{|c|}{ Month } \\
\hline & \multicolumn{2}{|c|}{ June } & \multicolumn{2}{|c|}{ July } & \multicolumn{2}{|c|}{ August } & \multicolumn{2}{|c|}{ September } & \multicolumn{2}{|c|}{ Period: June - September } \\
\hline & ICD & $\%$ & ICD & $\%$ & ICD & $\%$ & ICD & $\%$ & ICD & $\%$ \\
\hline Non-irrigated & 10.7 & 100 & 9.7 & 100 & 6.7 & 100 & 12.0 & 100 & 9.8 & 100 \\
\hline Irrigated & 15.0 & 140 & 17.4 & 179 & 17.5 & 261 & 16.1 & 134 & 16.5 & 168 \\
\hline
\end{tabular}


Table 7.Total water consumption and the supplying water sources for the non-irrigated and irrigated autumn cabbage crops

\begin{tabular}{cccccccc}
\hline \multirow{2}{*}{ Variant } & \multicolumn{4}{c}{ Total water consumption } & \multicolumn{3}{c}{ Supplying sources } \\
& \multicolumn{2}{c}{ Average } & Variation range & Soil reserve & Rainfall & Irrigation \\
& $\mathrm{m}^{3} / \mathrm{ha}$ & $\%$ & $\mathrm{~m}^{3} / \mathrm{ha}$ & $\%$ & $\mathrm{~m}^{3} / \mathrm{ha}$ & $\mathrm{m}^{3} / \mathrm{ha}$ & $\mathrm{m}^{3} / \mathrm{ha}^{-}$ \\
\hline Non-irrigated & 3,045 & 100 & $1,073-4,421$ & 100 & 656 & 2,389 & 2,410 \\
\hline Irrigated & 5,180 & 170 & $4,375-5,826$ & $19-972$ & 380 & 2,389 & 2,410 \\
\hline
\end{tabular}
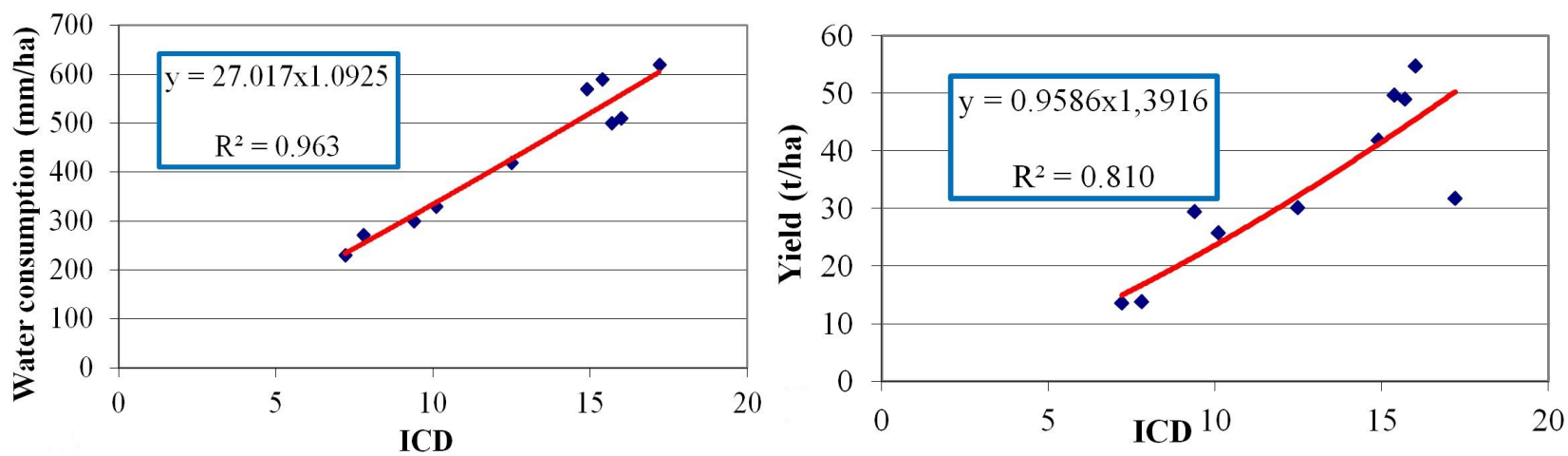

Fig. 2. Correlation of the Domuța climate index (ICD) in autumn cabbage crop

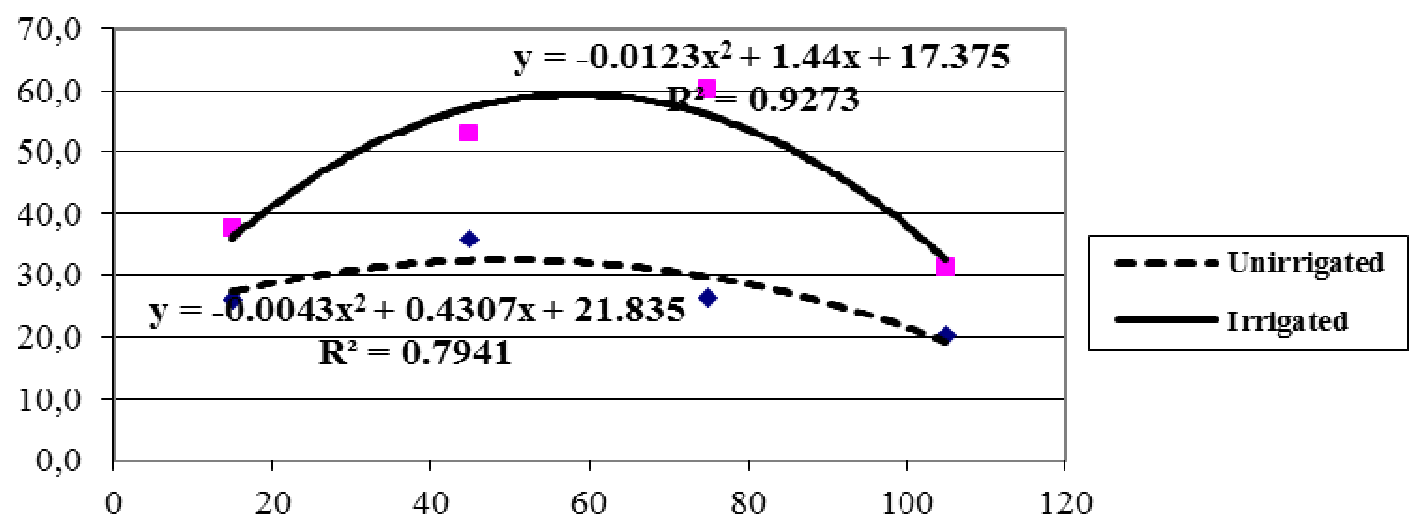

Fig. 3. Modelling of the daily water consumption for irrigated and non-irrigated autumn cabbage crops, Oradea, 1990-2016

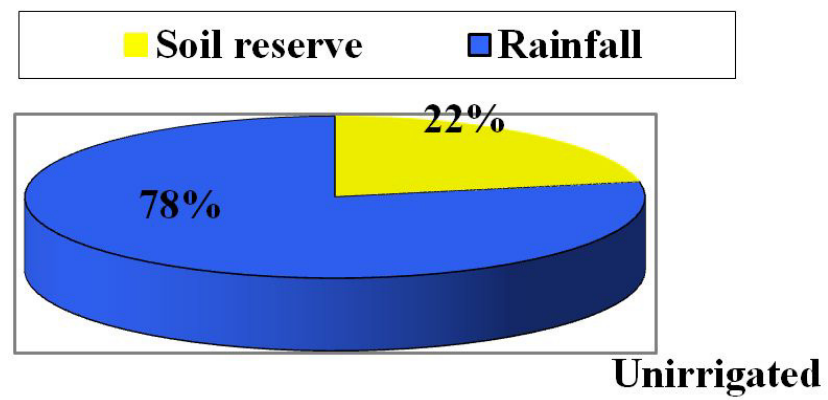

$\square$ Soil reserve $\square$ Rainfall $\square$ Irrigated

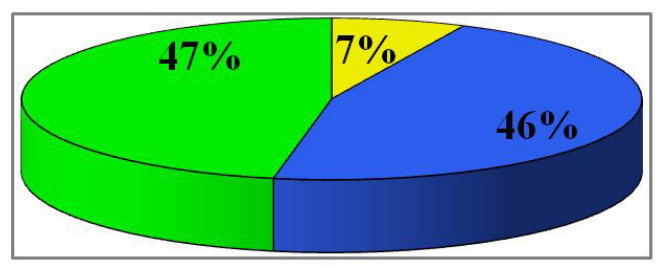

\section{Irrigated}

Fig. 4. Sources for supplying (\%) the total water consumption for non-irrigated and irrigated autumn cabbage crops, Oradea, $1990-2016$

The influence of irrigation on the yield of autumn cabbage

Irrigation resulted in a statistically significant increased average yield of cabbage of $53,256 \mathrm{~kg} / \mathrm{ha}$ when compared to $21,050 \mathrm{~kg} / \mathrm{ha}$, the yield of non-irrigated cabbage. Throughout the studied years, the differences registered were very significant, statistically speaking; the standard deviation of the irrigated yield $(1,760 \mathrm{~kg} / \mathrm{ha})$ decreased by $76 \%$ compared to the non-irrigated yield of autumn cabbage. The variation range of the yield was 0 (during three years) $-50,990 \mathrm{~kg} / \mathrm{ha}$ for the non-irrigated autumn cabbage, while it was between $27,150-66,130 \mathrm{~kg} / \mathrm{ha}$ for the irrigated one (Table 8).

The percentage of irrigated cabbage heads was of $98 \%$, higher than that of the non-irrigated ones which was of $79 \%$. Statistically, the difference $(24 \%)$ was very significant under the study interval 1990-2016. The variation range of the percentage was of $0-90 \%$ for the non-irrigated cabbage heads and of $88-100 \%$ for the irrigated ones (Table 9). 
Table 8. The influence of irrigation on the yield of non-irrigated and irrigated autumn cabbage crops, Oradea, 1990-2016

\begin{tabular}{|c|c|c|c|c|c|c|}
\hline \multirow{3}{*}{ Variant } & \multicolumn{4}{|c|}{ Average } & \multirow{3}{*}{$\begin{array}{c}\text { Variation range } \\
\mathrm{kg} / \mathrm{ha}\end{array}$} & \multirow{3}{*}{$\begin{array}{c}\text { Standard deviation } \\
\mathrm{kg} / \mathrm{ha}\end{array}$} \\
\hline & \multirow{2}{*}{$\mathrm{kg} / \mathrm{ha}$} & \multirow{2}{*}{$\%$} & \multicolumn{2}{|c|}{ Difference } & & \\
\hline & & & $\mathrm{kg} / \mathrm{ha}$ & $\%$ & & \\
\hline Non-irrigated & 21,050 & 100 & - & - & $0-50,990$ & 7,200 \\
\hline Irrigated & 53,256 & 253 & 32,206 & 153 & $27,150-66,130$ & 1,760 \\
\hline
\end{tabular}

Table 9. The influence of irrigation on the percentage of cabbage heads

\begin{tabular}{cccccc}
\hline \multirow{2}{*}{ Variant } & \multicolumn{2}{c}{ Cabbage heads } & & Difference & \multicolumn{2}{c}{ Variation range } \\
\cline { 2 - 6 } & Value & $\%$ & $\%$ & $0-90$ \\
\hline Non-irrigated & 79 & 100 & 124 & 24 & $88-100$ \\
\hline Irrigated & 98 & &
\end{tabular}

$\mathrm{LSD}_{5 \%}=6 ; \mathrm{LSD}_{1 \%}=9 ; \mathrm{LSD}_{0.1 \%}=16$

Table 10. Water use efficiency (WUE) and irrigation water use efficiency (IWUE) in autumn cabbage crops

\begin{tabular}{cccccc}
\hline \multirow{2}{*}{ Variant } & \multicolumn{3}{c}{ WUE } & \multicolumn{2}{c}{ IWUE $\left(\mathrm{kg}\right.$ yield gain $\left./ \mathrm{m}^{3}\right)$} \\
\cline { 2 - 6 } & $\mathrm{kg} / \mathrm{m}^{3}$ & $\%$ & Variation range & Average & Variation range \\
\hline Non-irrigated & 6.91 & 100 & $0-8.18$ & - & $6.76-23.46$ \\
\hline Irrigated & 11.8 & 160 & $4.70-13.12$ & 13.4 \\
\hline LSD $_{5 \%}=0.95 \cdot \mathrm{LSD}$
\end{tabular}

\section{Water use efficiency}

Water efficiency indicators show the amount of yield (yield gain) obtained for $1 \mathrm{~m}^{3}(\mathrm{~mm})$ of water or the amount of water used to obtain $1 \mathrm{~kg}$ of yield (yield gain). The study used the first category of indicators.

On average, throughout the studied period, water use efficiency for the irrigated cabbage was $60 \%$ higher than for the non-irrigated one: $11.8 \mathrm{~kg} / \mathrm{m}^{3}$ (variation range 4.7 $13.12 \mathrm{~kg} / \mathrm{m}^{3}$ ) for the irrigated cabbage and $6.91 \mathrm{~kg} / \mathrm{m}^{3}$ (variation range $0-8.18 \mathrm{~kg} / \mathrm{m}^{3}$ ) for the non-irrigated one. Irrigation water use efficiency recorded an average value of $13.4 \mathrm{~kg}$ yield gain $/ \mathrm{m}^{3}$ (variation range $6.7-24.2 \mathrm{~kg} / \mathrm{m}^{3}$ ) (Table 10).

\section{Discussion}

The paper lies on researches carried out during the period 1990-2016, on preluvo-soil within the Agricultural Research Station from Oradea. It highlights significant arguments regarding the necessity of irrigation as a basic technological element of the autumn cabbage.

The context of the research was that in which pedological drought (the decrease of the soil water reserve below the easily available water content on watering depth $0-50 \mathrm{~cm}$ ) was present every year. The highest number of days with pedological drought was recorded yearly during August, 27 days. The highest frequency of the phenomenon $(100 \%)$ was recorded in August and September. Reverse correlations between the pedological drought and the water consumption, as well as the cabbage yield and direct correlations between the pedological drought and the irrigated yield gain were determined, all of them significant.

The research came as a data to be added on to existing works that highlight the necessity of irrigation to maintain the soil water reserve between easily available water content and field capacity on a depth of $0-50 \mathrm{~cm}$. Previous authors such as Seidel et al. (2017) highlighted the importance of irrigation in a complex system of horticultural measures as a key to obtain high yields. The deficit of irrigation as a component of sustainable crop growth method had effects in actual plant size and leaves area, head fresh weight size and total yield, as proven by Xu and Leskovar (2014). In order to achieve the goals set up by using irrigation, the average value of the irrigation rate was of $2,410 \mathrm{~m}^{3} / \mathrm{ha}$, with a variation range between 1,330 and $4,660 \mathrm{~m}^{3} / \mathrm{ha}$.

Using the Domuta index allowed the authors to have an original approach on the data interpretation and gave the opportunity to highlight the improved ratio between rainfall + air humidity/air temperature + sunshine duration. Consequently, the value of the Domuta climate index (ICD) increased by $68 \%$ (wet II vs. wet); the variation range of the difference between the irrigated and nonirrigated cabbage crops was of $12-359 \%$. A statistically assured direct correlation between ICD and the water consumption, respectively the autumn cabbage yield was thus determined, also referring to previous posts about this were done by Domuța et al. (2008).

Irrigation helped obtain an optimal daily water consumption of the autumn cabbage. The highest difference between the daily water consumption for the irrigated cabbage and the daily water consumption for the non-irrigated cabbage was recorded in August, $128 \%$. As a consequence, total water consumption increased by $70 \%$. At the same time, the modelling of the daily water consumption values showed a polynomial function, with a higher correlation coefficient for the irrigated crop compared to the non-irrigated one. A paper to support this claim was published by Domuța et al. (2015), underlined the effects of the water consumption increase in cabbage as opposed to Costa et al. (2007) who concluded that in the context of water shortages, deficit irrigation can have some positive effects. The issue of deficit irrigation was also looked into by Xu and Leskovar (2014). Another point of discussion is the use of irrigation in supplying the optimal 
588

water consumption for the cabbage. On the average, throughout the studied period, the percentages of the optimal water consumption supply were: irrigation $47 \%$, rainfall from planting to harvesting $46 \%$ and soil water reserve $7 \%$; one of the papers that had a claim similar was published by Domuța et al. (2008).

Irrigation led to a yield gain of $153 \%, 53,256 \mathrm{~kg} / \mathrm{ha}$ vs. $21,050 \mathrm{~kg} / \mathrm{ha}$ respectively. Throughout the studied years, irrigation led to a very significant yield gain, statistically speaking. In three years, the yield of the non-irrigated cabbage crop was insignificant, it also generated improved stability: $1,760 \mathrm{~kg} / \mathrm{ha}$ vs. $7,200 \mathrm{~kg} / \mathrm{ha}$. The correlation between open field agriculture and it's results were highlighted by Csok et al. (2007).

The study points out a very significant statistically increase of cabbage heads: $98 \%$ vs. $79 \%$. Irrigation ensured a percentage of over $95 \%$ of cabbage heads to be marketable according to Smittle et al. (1994). The goal of modern horticulture in the end is to obtain as much end product as possible, with a high marketable potential. This is what irrigation ultimately abides us to, and the two reference papers, although 20 years some apart, reach the same conclusion, to highlight the importance of irrigation. Water use efficiency improved 11.8 vs. $6.91 \mathrm{~kg} / \mathrm{m}^{3}$, with a very significant statistically meaning. Allen et al. (1998) came to lay the foundation for basic water use efficiency and crop evapotranspiration, thus providing the link between nonirrigated water use efficiency versus irrigated water use efficiency.

\section{Conclusions}

The yearly presence of the pedological drought, the positive influence of irrigation on microclimate and water consumption, the statistically very significant annual yield gain and all the correlations of the soil - water - plant atmosphere system, enhance the idea that irrigation is a pivotal element that impose to be used for the autumn cabbage crop within Crisurilor Plain, Romania, without whom the yield drops significantly.

\section{References}

Allen RG, Pereira LS, Raes D, Smith M (1998). Crop evapotranspiration: guidelines for computing crop water requirements. In: Proceedings of the Irrigation and Drainage Paper No. 56. Food and Agricultural Organization, United Nations 300(9):D05109.

Apahidean AS, Apahidean M, Laczi E, Ivan I, Apahidean AI, Zagraian C (2011). Variety and plant density influence upon the yield of autumn white headed cabbage. Bulletin USAMV Cluj-Napoca 68:1.

Costa M, Ortuno MF, Chaves MM (2007). Deficit irrigation as a strategy to save water: physiology and potential application to horticulture. Journal of Integrative Plant Biology 49:1421-1434.

Csok E, Apahidean AS, Apahidean M, Buta M (2007). Studies concerning the influence of environmental conditions and protecting method on early cabbage production cultivated in open field. Bulletin USAMV Cluj-Napoca 64:337.

Domuţa C (1995). Contributions to determining water consumption of the main crops from Crişurilor Plain. PhD Thesis, Academy of Agricultural and Forestry Sciences "Gheorghe Ionescu Şişești".
Domuţa C, Şcheau V, Şandor M, Borza I, Samuel A (2008). Irrigation influence on water use efficiency in autumn cabbage crop from Crisurilor Plain and irrigation scheduling by Pan Evaporation method. Scientific pappers series B-LI- Horticulture USAMV Bucuresti 51:5662.

Domuța Cr, Borza I, JudeE, Cenușa N (2015). Irrigation the component of the sustainable technology of the autumn cabbage from Crişurilor Plain. Natural Resources and Sustainable Development 41-48.

Frantz J, Welbaum G, Zhengxing S, Morse R (1999). Comparison of cabbage seedling growth in four transplant production systems. Hort Technology 9:128-133.

Jones HG (2004). Irrigation scheduling: advantages and piffalls of plant based methods. Journal of Experimental Botany 55:2427-2436.

Laczi E, Apahidean Al, Luca E, Dumitraş A, Boancă P (2014). The growth, development and yield of headed chinese cabbage in autumn protected culture in transylvanian tableland specific conditions. AgricultureScience and Practice 1-2.

Posta G, Berar V (2007). Researches concerning the yield performances of the early cabbage hybrids cultivated in the field conditions. Bulletin USAMV Cluj-Napoca 64:113-117.

Samuel AD, Domuța C, Şandor M, Vuşcan, A, Brejea R (2011). Long term effects of agricultural systems on soil phosphatase activities. Romanian Agricultural Research 28:157-163.

SeidelJ, Werisch S, Schütze N, Laber H (2017). Impact of irrigation on plant growth and development of white cabbages. Agricultural Water Management 187:99-111.

Smittle D, Dickens L, Stansell J (1994). Irrigation regimes affect cabbage water use and yield. Journal of American Horticultural Sciences 119(1):20-23.

Stoleru V, Imre A (2007). Growing vegetables by organic methods (in Romanian). Risoprint Cluj-Napocapp 52-105.

Sturm M, Kacjan-MarsicN, Zupanc V, Bracic-Zeleznik B, LojenS, Pintar $\mathrm{M}$, (2010). Effect of different fertilisation and irrigation practices on yield, nitrogen uptake and fertiliser use efficiency of white cabbage (Brassica oleracea var.capitata L.). Scientia Horticulturae 125:103-109.

Tiwari KN, Mal PK, Singh RM, Chattopadhyay A (1998a). Response of okra (Abelmoschus esculentus (L.) Moench.) to drip irrigation under mulch and non-mulch conditions. Agricultural Water Management 38:91-102.

Tiwari KN, Mal PK, Singh RM, Chattopadhyay A (1998b). Feasibility of drip irrigation under different soil covers in tomato. Journal of Agricultural Engine 35:41-49.

Tiwari KN, Singh A, Mal PK (2003). Effect of drip irrigation on yield of cabbage (Brassica oleracea L. var. capitata) under mulch and non-mulch conditions. Agricultural Water Management 58:19-28.

Xie J, Cardenas ES, Sammisa TW, Wall MM, Lindsey DL, Murray LW (1999). Effects of irrigation method on Chile pepper yield and phytophthora root rot incidence. Agricultural Water Management 42:127-142.

Xu C, Leskovar DI (2014). Growth, physiology and yield responses of cabbage to deficit irrigation. Horticultural Science 41(3):138-146. 